IZA DP No. 5611

Labor Market Dynamics in Tunisia:

The Issue of Youth Unemployment

Marco Stampini

Audrey Verdier-Chouchane

March 2011 


\title{
Labor Market Dynamics in Tunisia: The Issue of Youth Unemployment
}

\author{
Marco Stampini \\ African Development Bank \\ and IZA
}

\author{
Audrey Verdier-Chouchane \\ African Development Bank
}

\author{
Discussion Paper No. 5611 \\ March 2011 \\ IZA \\ P.O. Box 7240 \\ 53072 Bonn \\ Germany \\ Phone: +49-228-3894-0 \\ Fax: +49-228-3894-180 \\ E-mail: iza@iza.org
}

\begin{abstract}
Any opinions expressed here are those of the author(s) and not those of IZA. Research published in this series may include views on policy, but the institute itself takes no institutional policy positions.

The Institute for the Study of Labor (IZA) in Bonn is a local and virtual international research center and a place of communication between science, politics and business. IZA is an independent nonprofit organization supported by Deutsche Post Foundation. The center is associated with the University of Bonn and offers a stimulating research environment through its international network, workshops and conferences, data service, project support, research visits and doctoral program. IZA engages in (i) original and internationally competitive research in all fields of labor economics, (ii) development of policy concepts, and (iii) dissemination of research results and concepts to the interested public.
\end{abstract}

IZA Discussion Papers often represent preliminary work and are circulated to encourage discussion. Citation of such a paper should account for its provisional character. A revised version may be available directly from the author. 


\section{ABSTRACT \\ Labor Market Dynamics in Tunisia: The Issue of Youth Unemployment}

This paper analyzes the dynamics of the youth labor market in Tunisia using unique labor force survey data from 2005 to 2007 that include a longitudinal component. It first shows that sustained economic growth will reduce youth unemployment over the next few years. Second, forecasts indicate that the growth of private sector services has the highest potential to reduce youth unemployment. Third, the analysis of labor market characteristics reveals that young graduates experience long unemployment as they cue for high-skill jobs. Moreover, the public sector remains the main provider of employment opportunities for many graduates, in particular for women.

JEL Classification: J21, J64, J68, J71

Keywords: $\quad$ labor market, unemployment, youth, Tunisia

Corresponding author:

Marco Stampini

African Development Bank

BAD-EDRE, B.P. 323

1002 Tunis

Tunisia

E-mail: m.stampini@afdb.org

\footnotetext{
* The paper is developed from a collaborative study conducted by the Development Research Department and the Regional Operations Department North-1 of the African Development Bank, and by the Tunisian National Institute of Statistics (INS). The authors remain grateful to Mr. Khalifa Ben Fekih, Director General of the Tunisian National Institute of Statistics (INS) for granting access to the data, and to Messieurs Habib Fourati (Director), Souheil Chebbi and Yamen Helel, from the Department of Demographic and Social Statistics, for invaluable help with data management and analysis. Colleagues from the African Development Bank who provided useful comments during several departmental and inter-departmental presentations are duly acknowledged. In particular, we would like to thank Léonce Ndikumana, Vincent Castel, Abdul B. Kamara and Désiré Vencatachellum and Shimeles Abebe for comments and support. Any remaining error is the authors' responsibility only. The findings of this paper reflect the opinions of the authors and not those of the African Development Bank, its Board of Directors or the countries they represent.
} 


\section{INTRODUCTION}

During the last 10 years, Tunisia has achieved consistently good macroeconomic performances. Real Gross Domestic Product (GDP) growth amounted on average to 5 percent a year, and reached a record high 6.3 percent in 2007. Nonetheless, the Tunisian economy is characterized by high unemployment (14.2 percent in 2010). In particular, the high rate of unemployment among young graduates -which reached 47 percent in 2007 for individuals aged 23-29 years with a Master degree in law, economics and management- constitutes one of the key development challenges for the country.

The former Government of Tunisia included the problem of youth unemployment among the priorities of the Eleventh and Twelfth Development Plan. However, progress towards its solution was slow. It is telling that the violent political protests which led to the departure of former President Ben Ali on 14 January 2011 were sparked by the public self immolation of a youth who had seen his informal business confiscated by the police in the interior of the country.

This paper aims to address the following research questions: 1) What is the relationship between GDP growth and youth employment generation in Tunisia? 2) Given the expected trends of demographic growth and labor force participation, how is youth unemployment likely to evolve in the next ten years? 3) Which sectors are most likely to contribute to the reduction of youth unemployment? 4) How does education affect labor market participation, mobility and the incidence and duration of unemployment? 5) Are there signs of existence of a gender gap, i.e., do women enjoy equal opportunities on the labor market?

Relative to the existing literature, our work is novel in several respects. First, it exploits rarely available nationally representative data from the very rich Labor Force Surveys (LFSs) carried out by the Tunisian National Institute of Statistics (INS) in 2005, 2006 and 2007. The high quality of the data and the large size of the samples allow a detailed analysis of the characteristics of the Tunisian labor market. Second, this study is the first to exploit the 200506 panel component of the LFSs. This allows studying the labor market dynamics of graduates as compared to non-graduates, looking at mobility across labor force statuses and across sectors of activity. Previous work by the Ministry of Employment and Professional Integration of the Youth and the World Bank (2008) relies on a sample made only of graduate individuals and therefore lacks a control group. Third, we combine the analysis of labor mobility with the analysis of economic growth and demographic trends to forecast youth unemployment over the next ten years.

The remainder of the paper is organized as follows. Section 2 provides a brief survey of the existing literature on the Tunisian labor market. Section 3 describes the data, defines the key concepts that will be used in the following sections, and outlines the methodology for the analysis of the labor market. Section 4 analyzes the trends of GDP growth and employment generation, and forecasts unemployment for the near future, based on the expected evolution of the active population. Section 5 provides a profile of characteristics of the Tunisian labor market and discusses its dynamics. Section 6 concludes and provides policy recommendations. 


\section{EXISTING LITERATURE}

Most of the existing literature on employment in Tunisia adopts a macroeconomic perspective. Part of it focuses on the evolution of labor demand and supply in a context of sustained growth, and on the net effect on unemployment (The World Bank, 2004a; Boughzala, 2004; Nabli et al., 2007; Redjeb and Ghobentini, 2005).

The effect of GDP growth on employment is measured by the GDP elasticity of employment. Most estimates of this elasticity across countries, time and sectors, range from 0.2 to 0.8 (see Tables A1.1, A1.2 and A1.3 in Annex 1 for a comprehensive survey). This implies that growth is generally associated with increasing labor productivity ${ }^{2}$ (or, in other words, with reduced labor intensity). However, some exceptions are worth noting.

In the Middle East and North Africa region, the agricultural sector experienced employmentintensive growth from 1991 to 2003, with an elasticity of 1.06. Hence, agriculture remains a fundamental sector for employment creation. In Tunisia, the GDP elasticity of employment in the period 1989-2001 varied between -0.1 and 1.6 for the agricultural sector, between 0.5 and 0.7 for the manufacturing industry, and between 0.5 and 1.1 for services (The World Bank, 2004b; see Table A1.1).

A second stream of literature focuses on the effects of regional integration and trade liberalization (The World Bank, 2004b; Dennis, 2006), and analyze the consequences of the end of the multi-fibers agreement on the textile manufacturing industry (Marouani, 2004; Ben Ayed Mouelhi, 2007). The authors point out that without adequate reforms and policies, trade liberalization will cause an increase in unemployment and wage inequality in Tunisia.

A study by the Tunisian Ministry of Employment and Professional Integration of the Youth (ME) and the World Bank (2008) analyzes the employment opportunities of a sample of university graduates. The report focuses on the transition from university to employment, using a sample of 4,763 individuals graduated in 2004 and surveyed at regular intervals for eighteen months after graduation. It finds that unemployment is widespread (46 percent) and higher for women (51 percent versus 38 percent for males). The highest unemployment rate was recorded for graduates in Law, at 68 percent (ME and The World Bank, 2008). ${ }^{3}$

About 38 percent of the sample remained unemployed for the whole 18 months covered by the survey; 17 percent left unemployment to participate in a program of professional integration; 19 percent never participated in the labor force, remaining inactive for the whole period, and deciding in some instances to return to school (ME and The World Bank, 2008). The remaining 26 percent found a job.

Wage employment constituted 71 percent of total employment in the sample. Selfemployment was rare and generally limited to architects, pharmacists and physicians. The public sector was the main employer, providing 52 percent of salaried jobs, mostly in

\footnotetext{
${ }^{2}$ In fact, GDP employment elasticity and labor productivity are inversely related. Values of the elasticity above one imply a drop in labor productivity, while values of the elasticity below one imply that labor productivity is growing.

${ }^{3}$ These results do not correspond exactly to those that we find in Table A4.3 in Annex 4, because the samples differ. In fact, while ME and The World Bank (2008) focus on the eighteen months that follow university graduation, we consider all young graduates aged 23-29 years.
} 
education and health. ${ }^{4}$ Mismatch between job characteristics and worker skills was common; it was recorded for 15 percent of individuals with a Masters degree and for 33 percent of vocational trainees. ${ }^{5}$ About half of those employed in the private sector declared to be looking for a better job, mainly because of the short-term or informal nature of their current employment (ME and The World Bank, 2008).

The existing literature shows that the high unemployment rate in Tunisia is driven by a rapid expansion of the labor force. The increasing participation of women in the labor market explains part of the phenomenon, although female labor force participation is still lower than should be expected given the trend in women's educational attainment and the decline in fertility (The World Bank, 2004b). The analysis of labor market outcomes provides evidence of gender inequality. The gender parity ratio, defined as the ratio of female to male unemployment rates, increased from 1.1 in 2000 to 1.3 in 2005 (Nabli et al. 2007). In addition, the gender wage gap amounts to 14 percent, at parity of education and other worker characteristics (The World Bank, 2004b).

The high unemployment rate among graduates is due to the fact that the demand for skilled labor comes mainly from the public administration (Boughzala, 2004; The World Bank, 2004b), whose growth is constrained by budgetary reasons and by increasing privatization and deregulation. On the other hand, the main providers of private sector employment (agriculture, textile industry and constructions) demand unskilled workers. The World Bank (2004b) forecasts an unemployment rate for graduates of 28 percent in 2016, with new entrants in the labor markets (fresh from school) accounting for over half of job seekers. Therefore, "creating more and better jobs would call for moving up the value-added ladder, towards higher-skill exports and services, while facilitating the emergence of the knowledge-based economy in the long-term” (The World Bank, 2004b, p. 17).

\section{DATA, DEFINITIONS AND METHODOLOGY}

\subsection{Data}

Our analysis is based on complementary data sources on production and demographic trends, and on individual level data from three Labor Force Surveys (LFSs).

Time series on population, active population and unemployment rate are from the International Labor Organization (ILO)'s Labor Statistics data set. ${ }^{6}$ The time series on GDP are from the Tunisian National Institute of Statistics (INS), which also supplied the GDP by sector of production.

The analysis of the labor market is based on data from three Labor Force Surveys (LFSs) from 2005, 2006 and 2007. More specifically, the static analysis is based on the most recent LFS, from 2007, which surveyed about 464 thousand adult individuals. We focus on 67,150 young non-enrolled individuals aged 23 to 29 . The choice of the lower bound is due to the need to compare university graduates with alike non-graduates, as 23 years is the youngest age at

\footnotetext{
${ }^{4}$ The ME and the World Bank (2008) rely on a very refined definition of public and private employment. In fact, the private nature of the employer is recorded in every sector but the public administration.

${ }^{5}$ The ME and the World Bank (2008) define "mismatch" as the percentage of graduates with a specific degree/specialty whose job is not related to the skills.

${ }^{6}$ See http://laborsta.ilo.org/
} 
which it is possible to enter the labor market after achieving a Masters (BAC+4). The upper bound is set at 29 rather than the usual 25 because of the need to maintain a sufficiently large sample size. We restrict the sample to non-enrolled individuals because we aim at assessing the effect of achieved education on labor market performance, while students are in most cases inactive by definition. Moreover, the questionnaires of the LFS do not allow identifying the highest achieved degree for those currently enrolled (for example, vocational trainees may or may not have achieved a secondary degree (BAC)).

The dynamic analysis is based on a sample of about 11 thousand non-enrolled youth interviewed by the LFS in both 2005 and 2006. Results are conditional on not being enrolled in school at the time of any of the two surveys. We therefore focus on mobility within the labor market rather than on performance at entry.

\subsection{Definitions}

Higher education. We consider individuals with higher education those who completed at least a four-year university degree $(\mathrm{BAC}+4)$.

Labor market states. We consider five labor market states: inactivity, unemployment, regular wage employment, casual wage employment and self employment. The inactive and unemployed have not worked (or have worked less than one hour) during the last week before the interview. In line with the definition adopted by the country, the unemployed are either (a) looking for a job or (b) not looking for a job but willing to start working during the following two weeks if they receive an offer. Wage earners have been working for at least one hour during the week prior to the interview, and have received a salary. They are divided into regular employees and casual/seasonal, the latter being a proxy for informality. Finally, selfemployed have been working independently for at least one hour. These definitions are standard. We acknowledge that the employment categories include those that are underemployed, i.e. those who work less than they would like to.

Labor qualification (skill). We distinguish three levels of labor qualification, referring to the skill content of a job rather than to the education of the worker. Non-qualified jobs are the elementary occupations as defined by the International Standard Classification of Occupations (ISCO code 9). ${ }^{7}$ Jobs with intermediate qualification encompass clerical support, service and sales, skilled agriculture, forestry and fishery, craft and related trade, plant and machine operation and assembling (ISCO codes 4-8). High qualification jobs include managers, professionals and technicians (ISCO codes 1-3).

Sectors. In the following sections, we are interested in distinguishing public and private sector jobs. Unfortunately, we do not have access to precise information on the public or private status of the employing firm. We attempt to separate the sectors that are traditional domain of the public administration under the name of public services: these include water and electricity production and distribution, social and cultural services, education, health care and extraterritorial activities. Under the label of industry and private services, we group the manufacturing industry, mining and refining, construction, retail, transport and telecommunications, hotels and restaurants (which include most of tourism), banks and insurance, real estate and various repair activities. Although we are aware that part of these

\footnotetext{
${ }^{7}$ See http://www.ilo.org/public/english/bureau/stat/isco/docs/resol08.pdf.
} 
activities is of public property, we believe that the category represents a satisfactory proxy for the private sector in Tunisia.

Regions. In the multinomial logit regression, we include variables measuring residence in the following seven administrative regions: 1) District of Tunis (made of the Governorates of Tunis, Ariana, Manouba, Ben Arous); 2) North-East (Governorates of Nabeul, Zaghouan, Bizerte); 3) North-West (Governorates of Beja, Jendouba, Le Kef, Siliana); 4) Centre-West (Governorates of Kairouan, Kasserine, Sidi Bouzid); 5) Centre-East (Governorates of Sousse, Monastir, Mahdia, Sfax); 6) South-West (Governorates of Gafsa, Tozeur, Kebili); 7) SouthEast (Governorates of Gabes, Medenine, Tataouine).

\subsection{Methodology}

The analysis of the trends in youth unemployment is based on the projections on the size of active youth population and GDP growth, and on our own estimates of the GDP elasticity of youth employment. The latter is given by the ratio of youth employment growth to GDP growth, both in percentage terms.

The labor market profile is based on: a) descriptive statistics; b) the analysis of mobility between inactivity, unemployment and employment; c) the analysis of mobility across productive sectors, and; d) the multivariate analysis of the determinants of the labor force state, performed with a multinomial logit regression model.

The study of mobility across states or sectors is based on observed transition matrices, containing the conditional probabilities of transition. The conditional probability of transition to state (sector) $j$ in period $t$, conditional on being in state (sector) $i$ one year earlier $(t-1)$ is defined by the following expression:

$P_{i j}=\operatorname{Pr}\left(S_{t}=j \mid S_{t-1}=i\right)=\frac{\operatorname{Pr}\left(S_{t-1}=i \cap S_{t}=j\right)}{\operatorname{Pr}\left(S_{t-1}=i\right)}$

We study how individual characteristics affect the likelihood of being in either one of five labor force states: 1) inactivity, 2) unemployment, 3) regular wage employment, 4) casual or seasonal wage employment, and 5) self-employment. The multinomial logit model can be formalized as follows:

$\ln \Omega_{j \mid i}(X)=\ln \frac{\operatorname{Pr}(S=j \mid X)}{\operatorname{Pr}(S=i \mid X)}=X \beta_{j \mid i} \quad$ for $\mathrm{j}=1$ to 5

where $i$ is unemployment, used as reference state (omitted category). The log odds of being in state $j$ relative to being unemployed are a linear function of individual characteristics $X$. We obtain four vectors of coefficients (one for each labor market state $j=1$ to $5, j \neq i$ ).

The vector $X$ includes a set of individual characteristics, measuring: gender, university education, the interaction between gender and university education, age, the region of residence and living in rural areas. All variables are dichotomous, except for age. As some relevant variables may be omitted, we can consider our results in terms of correlation rather than causality. 
The value added of the estimation of model (2) relative to a descriptive analysis of the characteristics of the individuals in each labor market state, is that the multinomial logit coefficients isolate the effect of each characteristic, while controlling for the others.

\section{YOUTH UNEMPLOYMENT OUTLOOK}

GDP in Tunisia grew on average by 5 percent a year between 1999 and 2008. GDP grew by 5.55 percent in 2006, and 6.31 percent in 2007. In the same years, youth employment grew respectively by 2.6 percent and 0.3 percent (see Annex 2). This translates in a highly volatile GDP elasticity of employment, amounting to 0.47 in 2006 and 0.05 in 2007 (with a non-linear average value of 0.24 for the period 2005-07). ${ }^{8}$ The fact that the value of the elasticity is below 1 and declining suggests that the Tunisian economy is becoming less youth-labor intensive.

Youth labor market participation reached a peak of 54.2 percent in 2006, with the economically active youth growing more rapidly than the youth population. Coupled with the low value of the GDP elasticity of youth employment in 2007, this translated in an increase in youth unemployment from 25.1 percent in 2006 to 26 percent in 2007.

The previous paragraphs suggest that the Tunisian economy generated additional employment opportunities, but that demographic trends and a transformation of the social structure led to an even faster growth in labor supply, resulting in non-decreasing levels of youth unemployment. ILO population and participation estimates suggest that this situation may change in the near future. In fact, the young population will grow at decreasing rates, and will start contracting from 2012. The youth labor force will follow a similar pattern. Making the assumptions that: (a) the GDP elasticity of youth employment will remain constant at 0.24 (the average for the period 2005-07), and; (b) GDP will grow by 1.6 percent in 2011 (as a result of the revolution $)^{9}$ and by a constant 4.5 percent from 2012; youth unemployment is expected to have peaked at 26.2 percent in 2008, to have currently decreased to 25.4 percent, and to further decrease to a value of 10.5 percent in 2018. The projection is illustrated in Figure 1 and in Annex 2.

\footnotetext{
${ }^{8}$ We are able to calculate the GDP elasticity of youth employment only for the period 2005-07 using micro data from the LFSs and population series from the ILO. We acknowledge that two observations do not allow drawing absolute conclusions. However, the same evidence is found when all adults are considered, in this case for a longer period. The yearly GDP elasticity of labor for all working age adults over the period 1999-2007 amounted to 0.66 .

While employment figures from the INS' LFS refer to the 23-29 years age group, data on young population and young active population from the ILO LABORSTA data set refers to the 20-29 years age group. We trust that this inconsistency, that we cannot avoid, does not significantly bias the trends we discuss.

${ }^{9}$ Forecasts from the African Economic Outlook Model (http://www.oecd.org/dataoecd/10/58/27115960.PDF), February 2011.
} 
Figure 1 - Youth unemployment outlook in Tunisia

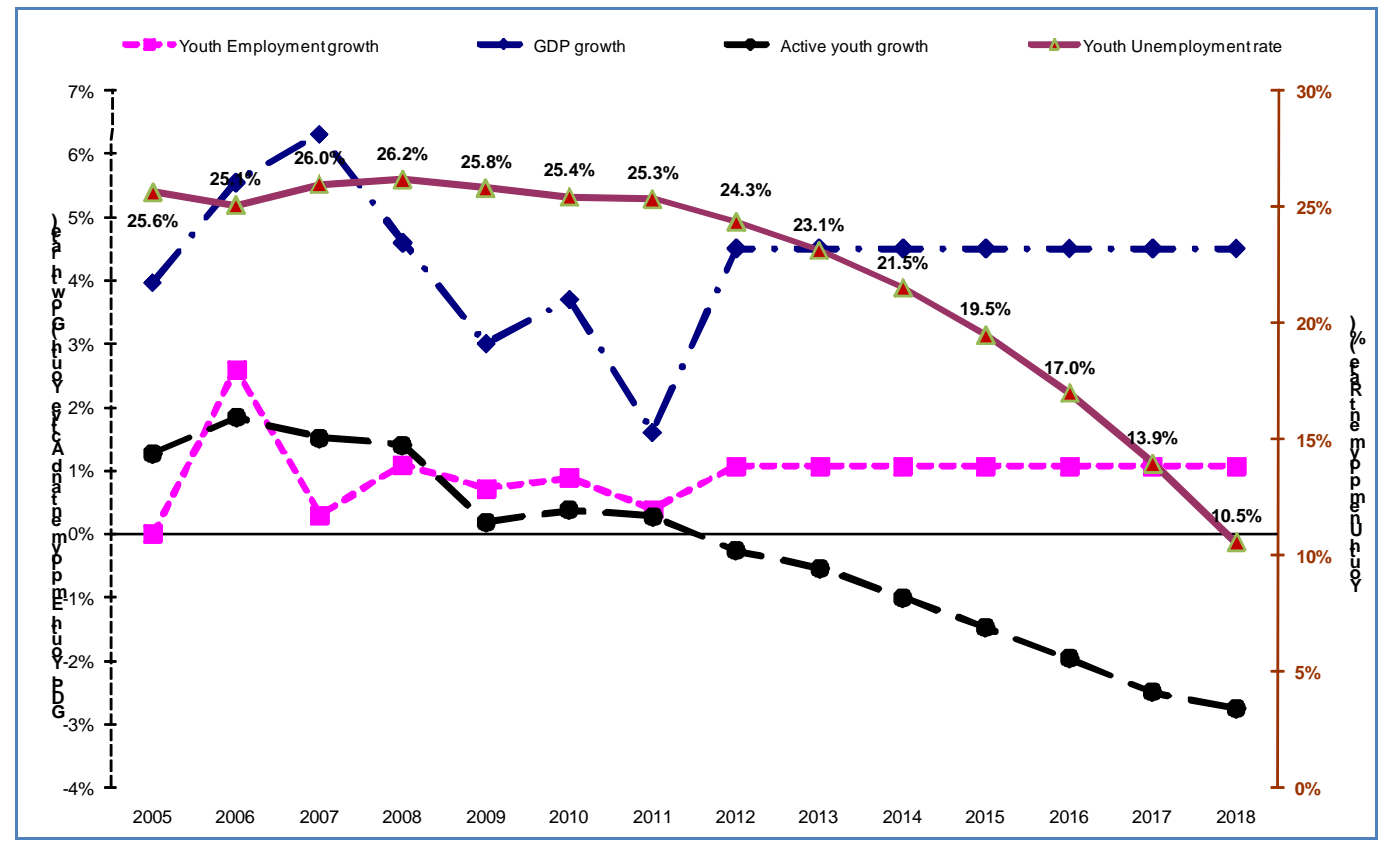

Source: Authors' calculations based on INS and ILO data, and authors' assumptions. Note: Youth unemployment rate measured on the right hand side axis.

However, the positive forecasts do not eliminate the concern of the Tunisian authorities for youth unemployment in the short and medium run, and the desire to actively fight unemployment to speed its downward trend. In order to shed light on the policy options, in the next sections we identify the sectors that most contribute to reducing youth unemployment, analyze the profile and dynamics of the youth labor market, and briefly look at the performance of the programs of professional integration. 


\section{ANALYSIS OF THE TUNISIAN LABOR MARKET}

All the evidence presented hereafter refers to non-enrolled individuals aged 23-29 years unless differently specified.

\subsection{Sector Analysis}

In 2007, the main employers of youth labor were the agricultural sector (14.3 percent), public administration (14 percent), construction (12.5 percent), and distribution and retail (11.6 percent). Social and cultural services, manufacturing of mechanical and electrical materials, transport and telecommunications and hotels and restaurants all accounted for about 5 percent of employment (Table A4.1 in Annex 4).

Seven economic sectors employed youth labor intensively, i.e. presented a ratio of the share of employed youth labor to the share of produced value added greater than one (Table A3.1 in Annex 3): textile manufacturing industry (2.75), constructions (2.16), other manufacturing (1.33), non-market services (1.32), agriculture, forestry and fishery (1.26), manufacturing of mechanical and electrical materials (1.2), and retail (1.1). Most of these sectors were important employers of youth labor, with at least 50,000 young workers.

In almost all sectors, the net generation of youth employment exceeded the growth rate of the youth active population -which averaged 1.7 percent over the period 2005-07 (see Table A3.1 in Annex 3). This was either due to intensification in the use of youth labor (relative to other labor) or to fast growth. The former is the case for the constructions sector, which absorbed youth labor and helped reducing youth unemployment despite below average value added growth rates. The latter is the case for retail and non-market services, which reduced the intensity of youth labor employment, yet helped reducing youth unemployment thanks to sustained value added growth. Some sectors experienced both fast growth and youth labor intensification. This is the case of tourism (largely part of 'hotels and restaurants') and mining and refining, whose GDP grew by 5.19 percent a year over 2005-07, while youth employment grew by 55.4 percent a year (with a record high elasticity of 13.29) (Table A3.1 in Annex 3, last column).

Only a few sectors did not contribute to reducing youth unemployment. These were agriculture, production of building materials, textile manufacturing, and other manufacturing, which either experienced negative or moderate growth of youth labor employment (Table A3.1, column 4).

The dynamic analysis on the 2005-06 panel sample shows that, even in those sectors that largely and increasingly employ youth labor, employment is often temporary. Only about 50 percent of youth working in construction, retail and hotels and restaurants are still employed in the same sector after one year (Table A3.2 in Annex 3). The result holds in general for all sectors (with retention rates ranging mostly between 50 and 60 percent), with the exception of non-market (mostly public) services, where only 25 percent of workers change sector or are job-less after one year. The effect of the end of the multi-fiber agreement in early 2005 on the textile industry labor mobility is worth noting. Out of every 100 workers in the textile sector in 2005, 38 had quit or lost their job after one year. However, only 11 had found another job; 8 had become unemployed, and a surprisingly high number of 20 had left the labor market to become inactive. This may be due to the fact that the sector intensively 
employs female unskilled labor, and that inactivity is particularly high among non-graduated women. Similar intensity of work-to-inactivity flows can be observed only for two other sectors: agriculture and social and cultural services.

The high turnover may have different non mutually-exclusive explanations. First, it is possible that there is a poor match between labor demand and supply. Firms do not find the most appropriate workers and skills, and vice-versa employees do not find the right job; for this reason, either part terminates the work relationship or the position is filled by another individual. Second, it is possible that employment is generally made of unskilled jobs. In this case, firms can easily replace workers, as there is not much job-specific human capital

accumulation. For the same reason, firms do not have incentives to pay efficiency wages above the market-clearing value. The consequence is that qualified workers have an incentive to quit their job and cue for public sector jobs (which seem to belong to the higher tier of a dual labor market). Poor match and absence of efficiency wages may be due to the fact that workers do not hold the skills required by the employers.

In order to investigate the existence of a skill gap or of a skill mismatch, it is necessary to study the relationship between education and type of employment.

\subsection{Education and type of Employment}

For every one hundred non-enrolled youth, 72 have not completed secondary school, 13 hold a high school degree (Baccalauréat or BAC), 6 completed a vocational training, and 9 a four years or longer university degree (Table A4.2 in Annex 4). Among university graduates, the most common disciplines are economics, management and law (31.5 percent of university graduates), social sciences (20.9 percent), hard sciences (11.8 percent) and engineering (9.9 percent).

Labor force participation is at 71 percent. Out of 100 active individuals, 49 hold a regular wage earning job, 8 a casual or seasonal wage earning job, 18 are self employed and 26 are unemployed (Table 1, last column).

Table 1 shows that university education is associated with a high rate of unemployment: 40 percent against 24 percent for non-graduates. However, non-graduates have a much lower rate of labor force participation: 68 percent against 95 percent for graduates. In other words, non-graduates without a job are less likely to look for one. As a result, graduates have a higher probability of employment: 57 graduates out of one hundred work, versus 52 among nongraduates. 
Table 1 - Labor Force State by education and gender

\begin{tabular}{l|ccc|ccc|ccc}
\hline & \multicolumn{3}{|c|}{ Non-graduates } & \multicolumn{3}{c|}{ Graduates } & \multicolumn{3}{c}{ Total } \\
& Males & Females & Total & Males & Females & Total & Males & Females & Total \\
\hline Inactive & 0.079 & 0.562 & 0.315 & 0.024 & 0.077 & 0.053 & 0.075 & 0.516 & 0.293 \\
Active & 0.921 & 0.438 & 0.685 & 0.976 & 0.923 & 0.947 & 0.925 & 0.484 & 0.707 \\
Total & 1.000 & 1.000 & 1.000 & 1.000 & 1.000 & 1.000 & 1.000 & 1.000 & 1.000 \\
\hline Active & & & & & & & & & \\
Unemployed & 0.232 & 0.263 & 0.241 & 0.328 & 0.461 & 0.399 & 0.240 & 0.299 & 0.260 \\
Regular wage earner & 0.440 & 0.568 & 0.480 & 0.587 & 0.487 & 0.534 & 0.452 & 0.554 & 0.486 \\
Casual wage earner & 0.105 & 0.038 & 0.084 & 0.018 & 0.020 & 0.019 & 0.098 & 0.034 & 0.076 \\
Self-employed & 0.224 & 0.131 & 0.195 & 0.066 & 0.032 & 0.048 & 0.211 & 0.113 & 0.178 \\
Total & 1.000 & 1.000 & 1.000 & 1.000 & 1.000 & 1.000 & 1.000 & 1.000 & 1.000 \\
\hline
\end{tabular}

Source: Authors’ calculations based on LFS 2007. Sample size: 67150

The unemployment rate varies by type of educational degree (Table A4.3 in Annex 4). It is lowest among individuals without secondary education (20.5 percent). Among university graduates, it is lowest for engineers (24.5 percent), and highest for graduates in economics, management and law (47.1 percent) and in social sciences (43.2 percent).

Formal employment, as proxied by regular wage employment, is positively associated with education, with the highest likelihood for engineers (69.7 percent, conditional on labor force participation), for those with a M.Phil or Doctorate (64.2 percent) and for scientists (53.5 percent). Generally low, casual and seasonal wage employment is highest for individuals with secondary education or less (respectively 5.1 percent and 9.9 percent). Self-employment seems to be practiced mainly by individuals with secondary education or less (16 percent and 22.3 percent, respectively), and by graduates in medicine and pharmacy (20.3 percent).

Education is positively correlated with work quality, proxied by skill level and share of wage employment regulated by a written contract. The left hand panel of Table A4.4 (Annex 4) shows that out of one hundred employed individuals with less than secondary education, 27 hold an elementary job, 65 a job with intermediate qualification, and only 8 perform a highskill job. At the opposite extreme, about 90 percent of employed engineers and graduates in medicine and pharmacy hold a high-skill job, and none an elementary one. It is interesting to notice that vocational training reduces the share of elementary work, but does not increase the share of high-skill work. Among employed university graduates, the lowest share of high-skill work is associated with a degree in 'economics, management and law' (59.5 percent). Written contracts, limited to wage earners, are associated with employment formality and suggest a similar picture, with two exceptions. The first is that vocational training remarkably increases the likelihood to hold a contract, to the level observed for university graduates. The second is that a relatively high share of graduates in medicine and pharmacy, despite the high level of skill of their job, work without a contract (22.5 percent).

As for the sector of employment ${ }^{10}$, holding a university degree is associated with a high probability of working in the public sector. About 56 percent of the graduates in medicine and pharmacy, and 49 percent of the graduates in social sciences and hard sciences, are employed in the public services (Table A4.5, Annex 4). The graduates in 'economics, management and law' and in engineering are notable exceptions, as only about 15 percent work in public

\footnotetext{
${ }^{10}$ The limited number of observations in some of the education categories imposes a simplified classification of economic sectors.
} 
services. In this case the main employing sectors are the industry and private services. Agriculture is the domain of those with less than secondary education.

Using a longitudinal sample of 11,000 youth observed in 2005 and 2006, we calculate the conditional probabilities of transition across labor force states. Because of the limited number of graduates in the sample, we consider three states only: inactivity, unemployment and employment. The first panel of Table A3.3 (Annex 3) shows that out of 100 non-graduates out of the labor force in 2005, 77 were still inactive in 2006; 7 were looking for a job, and 16 had found one. Out of 100 unemployed in 2005, only 36 were still unemployed one year later; 23 had stopped looking for a job, and 41 had found one. This translates in an average duration of unemployment of 19 months (Table 2). The dynamics of the graduates shows remarkable differences (Table A3.4 in Annex 3, panel A). First, the unemployment duration is longer. Out of 100 graduates unemployed in 2005, 58 were still jobless and in search of work one year later, and only 30 had found one (versus 41 among non-graduates). Therefore, the average duration of unemployment for those with a university degree is 28 months. Second, inactivity is mostly temporary. Out of 100 graduates out of the labor force in 2005, only 29 were still inactive one year later. A record high 46 had moved into unemployment, and 25 had found a job. Finally, once they find a job, graduates tend to hold it for a longer time. In fact, only 17 percent of graduates employed in 2005 were no longer employed in 2006, versus 22 percent of non-graduates.

Table 2 - Duration of unemployment in months, by education and gender

\begin{tabular}{lrrr} 
& $\begin{array}{r}\text { Non- } \\
\text { graduates }\end{array}$ & Graduates & Total \\
\hline Males & 19.9 & 28.2 & 20.5 \\
Females & 16.9 & 28.2 & 18.5 \\
Total & 18.8 & 28.2 & 19.7 \\
\hline
\end{tabular}

Source: Authors’ calculations based on LFS 2005 and 2006.

The aggregate picture, however, conceals important gender differences.

\subsection{Gender Differences}

At parity of education, women are less likely to be employed (Table 1). For individuals with secondary education or less, this is due to lower participation in the labor force. The inactivity rate is as high as 64 percent for women without secondary education and 32 percent for women with a secondary school degree (versus 9 and 3 percent for equally educated men) (Table A4.3 in Annex 4).

Holding a vocational training or a university degree reduces the differences in labor force participation, although 10.4 percent of female engineers are neither working nor looking for a job, compared with 1.6 percent for men. However, female graduates experience higher unemployment than male graduates. For instance, the rate of unemployment is highest for female graduates in economics, management and law at 53.4 percent - about 14 percentage points more than for males with equal qualification. The unemployment rate is at 37.1 percent among female engineers, against 20.7 percent for males. These differences hold in general, although they are substantially smaller for graduates in social sciences (41.1 percent for males and 44 percent for females). 
The record high inactivity rate among women with less than secondary education may be due to 'hidden unemployment', i.e. to young uneducated women not looking for a job because they have lost hope to find one. Another explanation may be that women choose to work at home instead of engaging with the labor market. The available data do not allow disentangling demand and supply side factors, hence both possibilities must be carefully considered.

Women are less likely than men to be self-employed. Table A4.3 in Annex 4 shows that selfemployment is a relevant option only for individuals with secondary education or less and for those with a university degree in medicine or pharmacy. However, this holds true only for men. Among individuals with less than secondary education, men are four times more likely than women to own their own business. The ratio is $2: 1$ for secondary school graduates, and 2.5:1 for graduates in medicine or pharmacy. Once again, this may be due either to barriers to the entry of women in self-employment, or to a preference for other labor market states.

Amongst the employed, women hold jobs with a lower level of qualification than equally educated men. For instance, 47.2 percent of young women with a degree in economics, management or law have a job with intermediate qualification, and 52.1 percent a job with high qualification. The corresponding percentages for men with the same degree are 31.4 and 66.7. Among physicians and pharmacists, 95.2 percent of men have a highly qualified job against 84 percent of women. This is unlikely to be due to supply side factors.

Among the active, women are less likely than men to be employed in the private sector. On the contrary, no gender differences or a slight preference for women are found in public sector employment. Table 3 presents an index of gender equality. The index is calculated, for each level of education, as the ratio of the share of females among the employees to the share of women in the active population. Values below one flag a bias in favor of men -while values above one signal a 'preference' for women. In the third column, it is evident that industry and private services tend to hire men more than women. For example, out of an equal number of male and female active engineers, the industry and private services sector hires 79 women for every 100 men. On the contrary, the public services sector hires 108 female engineers for every 100 men. The public services sector is the main provider of employment opportunities for women, and exhibits a slight bias in their favor.

The same evidence could also be explained by women's preference for public sector jobs over private sector employment. In this case, women would prefer cueing for a public sector job and would accept a period of unemployment rather than working in industry and private services. 
Table 3 - Index of gender equality, by education and sector of employment

$\begin{array}{lcccc}\text { Gender equality } & \text { Agriculture } & \begin{array}{c}\text { Industry and } \\ \text { market services }\end{array} & \begin{array}{c}\text { Non-market } \\ \text { services } \\ \text { (public) }\end{array} & \text { Unemployment } \\ \text { Less than secondary } & 0.97 & 1.01 & 1.14 & 0.94 \\ \text { Secondary (BAC) } & 0.80 & 0.90 & 1.24 & 1.07 \\ \text { Vocational training } & 0.97 & 0.69 & 1.15 & 1.16 \\ \text { Masters in Social Sciences } & 0.12 & 0.90 & 1.01 & 1.02 \\ \quad \text { Economics, Management or Law } & 0.94 & 0.83 & 1.04 & 1.13 \\ \text { Hard sciences } & 0.00 & 0.73 & 0.96 & 1.14 \\ \text { Other discipline } & 1.13 & 0.75 & 1.00 & 1.16 \\ \text { Degree in Engineering } & 0.86 & 0.79 & 1.08 & 1.48 \\ \text { Degree in Medicine or Pharmacy } & \text { NA } & 1.35 & 0.78 & 1.26 \\ \text { PhD } & 2.16 & 0.59 & 1.08 & 1.23\end{array}$

Source: Authors' calculations based on LFS 2007

Table A3.3 (Annex 3) shows very different patterns of mobility on the labor market for nongraduate men and women. For women, inactivity is a less temporary state. Not only 83 percent of women out of the labor force in 2005 were still inactive one year later, but also 44 percent of unemployed women and 29 percent of employed women had left the labor force. For men, the corresponding percentages are 36, 13 and 6. Symmetrically, employment is more temporary for women than for men. Women are less likely than men to hold a job (only 65 percent of them do, against 84 percent of men) or to find one starting from unemployment (only 27 percent do, against 48 percent of men). The duration of unemployment is shorter for women (17 months versus 20 for men (Table 2)) only because they leave the labor force.

Women with university education show patterns of mobility that are similar to those of equally educated men. First, active women are not more likely than men to leave the labor force. Second, women in unemployment are as likely as men to find a job. Third, employed women are as likely as men to keep their job. A remaining difference is that inactive women are more likely than inactive men to stay out of the labor force one year later (Table A3.4, Annex 3). These results are confirmed by the estimation of a set of conditional multinomial logit models, presented in Table A3.5 in Annex 3. The findings may be due to the fact that university education erases most of the gender differences in the patterns of labor mobility. However, they could also be result of self-selection, i.e. due to the fact that women pursuing university education have different inner characteristics that affect labor mobility.

\subsection{Education and Expectations}

As discussed above, university graduates are more likely to have qualified jobs and a written contract, and are mostly employed in the public sector. On the other hand, they experience higher unemployment rates and a longer duration of their unemployment (Table 2). On average, graduates' unemployment lasts nine months more than that of non-graduates (28.2 months instead of 18.8).

One possible explanation for the longer duration of unemployment among graduates is that skilled individuals cue for the best jobs -most often in the public administration- and prefer longer unemployment to taking up the available positions that do not match their expectations. 
In the words of the Financial Times (2008), 'the problems are compounded by a general disdain in the region for manual work and a tradition in many countries of providing secure, well paid jobs in the public sector for educated young people'. 'Though the public sector is no longer expanding, the majority of youth still appear to hunker after a government job and those that can afford it are prepared to remain unemployed for long periods in the hope of a vacancy turning up'. 'The scarcity of public-sector jobs has thus led to a rise in unemployment among graduates, especially women. One recommendation emerging from the six ILO country studies is the need to change young people's mindset, to encourage them to consider jobs in the private sector as well as the possibility of creating their own business" ${ }^{\text {"11 }}$. Although the idea of fostering youth entrepreneurship appears sensible, it must be considered that there are important objective barriers to starting a business, e.g. credit constraints. The problem must be addressed with comprehensive industrial policies tackling all constraints in a systematic way.

Another possible explanation for graduates' long unemployment is the lack of a good match between the skills provided by university education and the requirements of potential employers, in particular in the private sector. This is consistent with the evidence that the public sector remains the main provider of employment opportunities for many graduates.

The match between demand and supply of skilled labor may be improved by reforming the curricula for university education, and by involving the productive sectors in the design and implementation of training activities. Several studies recommend a reform of the educational system aimed at increasing the correspondence between the curricula and employers needs (Redjeb and Ghobentini, 2005; The World Bank, 2004a). Abid (2008) calls for a greater collaboration between universities and firms, and cites the ISET (Advanced Institutes for Technological Studies) as a successful model.

However, the problem may not be limited to university education. In fact, the latest PISA (Program for International Student Assessment) reports from the OECD (2009) shows that the quality of secondary education is relatively low relative to a sample of about 65 countries. Tunisia is consistently ranked among the last ten countries as far as 15 year old students' reading, mathematics and science skills are concerned ${ }^{12}$. A reform of primary and secondary education may have beneficial effects on the quality of the skills acquired by university graduates, and improve the match with firms' demand for skills.

For the existing pool of graduates -who cannot benefit from curricula reforms- it is important to improve the focus and the targeting of professional insertion programs. The government of Tunisia spends about 1.5 percent of GDP on these programs, which are successful in reducing unemployment in relative terms. Table 4 presents the post participation unemployment rate for individuals with different degrees. It also presents the ratio of the rate of unemployment among beneficiaries to the rate of unemployment among non-beneficiaries (index of relative effectiveness). All values are below 1, indicating a positive contribution of the programs to reducing unemployment. The lowest values (indicating best performance) are for individuals with vocational training, and for graduates in economics, management and law and in engineering. In all these cases, the programs of professional integration cut the rate of unemployment by more than 50 percent, relative to non-beneficiaries. Due to potential

\footnotetext{
${ }^{11}$ See http://www.ft.com/youth2008

${ }^{12}$ Tunisia is respectively ranked $56^{\text {th }}, 60^{\text {th }}$ and $55^{\text {th }}$ out of 65 countries in reading, mathematics and science skills.
} 
selection problems (the participants are not randomly selected), it is important to stress that this is not a rigorous assessment of the programs' efficacy.

Nonetheless, in 2007 only 5 percent of the youth in the LFS sample had benefited from a program of professional insertion ${ }^{13}$. About 11 percent did not know if they had participated, suggesting that the programs are not well known by the population.

Table 4 - percentage of unemployed after benefiting from a professional integration program, by education

\begin{tabular}{lcc}
\hline & $\begin{array}{c}\text { Post-participation } \\
\text { unemployment } \\
\text { rate }\end{array}$ & $\begin{array}{c}\text { Index of relative } \\
\text { effectiveness }\end{array}$ \\
\hline Less than secondary & 15.68 & 0.76 \\
Secondary (BAC) & 23.64 & 0.79 \\
Vocational training & 18.95 & 0.46 \\
Masters in Social Sciences & 29.22 & 0.68 \\
Economics, Management or Law & 21.18 & 0.45 \\
Hard sciences & 32.59 & 0.80 \\
Other discipline & 18.91 & 0.51 \\
Degree in Engineering & 9.09 & 0.37 \\
Degree in Medicine or Pharmacy & 15.53 & 0.53 \\
PhD & 7.13 & 0.27 \\
\hline
\end{tabular}

Source: Authors' calculations based on LFS 2007

\subsection{Multivariate Analysis}

We complement the descriptive analysis of the previous sections by analyzing the determinants of the position on the labor market through a multinomial logit model.

In multinomial logit regressions, one modality of the dependent variable is excluded and serves as reference -in our case unemployment. The estimated coefficients (one for each remaining modality $j$ ) can be read as the marginal effect of the variable on the probability of being in status $j$ relative to unemployment, which is the reference state.

Because of the small number of graduates, we are forced to include among the independent variables a single dummy variable for university degree rather than one for each alternative kind of degree, even more so given that we are interested in studying the interaction with gender. It is also worth noting that, as we include a dummy for gender, one for university degree, and their interaction, the coefficient on the variable 'female' expresses the marginal effect of female gender relative to male's among the non-graduates. With these explanations in mind, we can now analyze the effect of individual characteristics on the type of employment. The full results of the estimation are presented in Table A4.6 in Annex 4.

Among non-graduates, females are more likely to be either inactive or regular wage earners, and less likely to be casual/seasonal wage earners or self-employed (rather than unemployed) relative to equally educated men. This confirms the findings of the descriptive analysis carried out in the previous sections, and reassures that they were not due to the omission of age and regional considerations, for which we are now controlling.

\footnotetext{
${ }^{13}$ Evidence on participation in professional integration programs is limited to employed and unemployed individuals -as the question of interest was not asked to those who were out of the labor force.
} 
Among males, having a university degree reduces the likelihood of being in any other state but unemployment. In other words, all else being equal, a university degree increases the likelihood of unemployment. This is consistent with the hypothesis that graduates cue for a good job.

Except for self-employment, having a university degree reduces the difference between women and men. In fact, the sign of the coefficient on the interaction between gender and degree is opposite to the sign of the coefficient on gender only. In some cases the reduction is partial, and a difference persists: for example, women with a university degree are still more likely to be inactive than men with the same education. In the case of casual/seasonal wage earning, the difference is totally offset. In other cases, the balance shifts. For example, women with a university degree are less likely to be in regular wage employment than men, while amongst non-graduates the opposite holds. The only case in which education does not reduce gender differences is self-employment: women are less likely than men to be self-employed, no matter the level of education.

Relative to the youngest, the oldest in the sample are more likely to be in any labor force state than in unemployment. In other words, age reduces the likelihood of unemployment. This explains the difference between the unemployment rates presented in Table A4.3 and those estimated by the ME and the World Bank (2008), as the latter refer to newly graduates. As for inactivity, our result is probably driven by the exit from the labor force associated with marriage, within the context of a traditional one-earner family model. Those who do not leave the labor force tend to find a job (with equal probability for wage earning and selfemployment).

Living outside the District of Tunis makes it more likely to be either inactive, casually employed for wage or self-employed than to be unemployed. The only exception is the NorthWest, where inactivity is less likely than in Tunis, and where self-employment is equally likely. Relative to Tunis, regular wage employment is more likely than unemployment in the North-East and in the Centre-West, and less likely in all other regions. Overall, these results point to Tunis as a district where: i) labor force participation is higher; ii) access to regular wage employment is easier than in the rest of the country (except North-East and CentreWest), but also where; iii) the likelihood of unemployment is highest.

Relative to unemployment, living in rural areas increases the likelihood of inactivity, casual wage earning and self-employment, and reduces the chances to find regular wage employment.

\section{CONCLUSIONS AND POLICY RECOMMENDATIONS}

The problem of youth unemployment has reached the level of absolute priority for the national development policy in Tunisia. The problem has multiple causes. First, the size of the Tunisian young population has been increasing due to a demographic boom, and the rise in the number of university graduates has lead to increased labor market participation, in particular among women. Second, youth employment is short-lived, with about half positions renewed every year. Third, some of the youth-labor intensive sectors, such as the public administration, have recently recorded modest growth rates. 
Our projections, however, show a rosier future. If Tunisia maintains a growth momentum of 4.5 percent annually after 2011, the youth unemployment rate is forecasted to drop substantially in the forthcoming years. Therefore, continuing to implement the economic reforms aimed at sustaining economic growth is an absolute priority for the Government. This recommendation is in line with the findings of the World Bank (2004a), that recommends intensifying the process of liberalization in the markets for commodities, services and labor, and promoting the development of private small and medium enterprises through the improvement of the investment climate and of the quality of public services to the private sector.

At the same time, a few features of the youth labor market deserve immediate attention and action. University graduates looking for a job experience long periods of unemployment, on average as long as 28 months. They eventually obtain good quality jobs (with high levels of qualification and longer tenures), mostly as regular wage employees in the public sector. Low self employment mainly reflects entry barriers and constraints.

The problem must be addressed with comprehensive policies establishing an enabling environment for the development of the private sector and workers skills (Nabli et al., 2007). Dennis (2006) suggests that the effectiveness of structural reforms depends on the flexibility of the markets for inputs. The World Bank (2004a) and Boughzala (2004) criticize the rigidity of the regulation regarding the termination of work contracts, and identify it as one major constraint to industrial restructuring. In another work, the World Bank (2004b) finds that the public wage policies generate a bias in favor of the public sector - making employment in the private sector relatively less convenient.

Some gender differences must also be considered. First, labor force participation is much lower among women, although tertiary education is associated with a reduced gap. Second, graduate women experience higher unemployment rates. Third, while they are as likely as men to be employed in the public sector, they have a lower likelihood of employment in the private sector. Finally, they are more likely to hold temporary and less qualified jobs, and engage less in self-employment. Although some of these findings can be the result of women's preference for certain types of employment, the lower job qualification at parity of education is puzzling and worth addressing, for example in the context of active employment policies.

Programs of professional integration need to be reformed to improve the quality of the targeting. The World Bank (2004a) finds that the profile of the beneficiaries does not correspond to that of the unemployed, and recommends a greater focus on vulnerable adult individuals expelled from their job, rather than on first-job seekers only.

Finally, development policies should account for the regional differences highlighted by the multivariate analysis. The decentralization of the labor offices and the creation of job opportunities away from the capital and the Eastern coast may reduce the regional disparities. Redjeb and Ghobentini (2005) recommend a reform aimed to strengthen and decentralize the labor offices. They suggest that the network of labor offices be extended to cover the South and the interior of the country.

Unemployment benefits and public work programs for expelled workers are also under discussion. Notably, in January 2011 the interim government has announced a proposal of part-time employment in the public sector for unemployed youth graduates. These would 
work half time and receive a monthly payment of 150 Tunisian dinars (about Euro 77), equivalent to two thirds of the minimum wage (of 225 Tunisian dinars for 40 hours of work per week in the public sector in 2009). No study has been conducted to date on the sustainability of this program, and information is not available on the number of youths who would be interested in enrolling.

\section{References}

Abid, W. 2008. Le système éducatif en Tunisie: bilan et perspective. Paper presented at the Fourth International Conference on Les OMD Progrès et Perspectives: le cas des pays maghrébins, Hammamet, Tunisia, June 2008.

Ben Ayed Mouelhi, Rim. 2007. Impact of Trade Liberalization on Firm's Labor Demand by Skill: The case of Tunisian Manufacturing. Labor Economics 14, no. 3: 539-563.

Boughzala M. 2004. The Labor market in Tunisia. Study on the functioning of the labor markets in the Mediterranean Region and the implications for employment policy and training systems, University of Tunis.

Dennis A. 2006. Trade liberalization, factor market flexibility, and growth: the case of Morocco and Tunisia. World Bank Policy Research Working Paper 3857.

Marouani, Mohamed A. 2004. The Impact of the Multifiber Agreement Phase-out on Unemployment in Tunisia: a Prospective Dynamic Analysis. DIAL, ERF and Paris-Dauphine University/Eurisco. http://www.eudnet.net/workshops/afd_2004/Marouani.pdf

Ministère de l'Emploi et de l'Insertion Professionnelle des Jeunes and the World Bank. 2008. République Tunisienne, Dynamique de l'emploi et adéquation de la formation parmi les diplômés universitaires. Volume I : Rapport sur l’insertion des diplômés de l'année 2004.

Nabli, M. K., C. Silva-Jauregui and S. Johansson de Silva. 2007. Job Creation in a High Growth Environment - The MENA Region. MENA Working Paper Series no. 49, The World Bank.

OECD. 2009. PISA 2009 Results: What Students Know and Can Do. http://www.oecd.org/edu/pisa/2009

Redjeb M.S. and Ghobentini M. 2005. L’intermédiation sur le marché du travail en Tunisie. Cahiers de la Stratégie de l'Emploi n 2005/19, Unité de recherches et analyses sur l'emploi, Département de la Stratégie en matière d'emploi.

World Bank. 2004a. République tunisienne - Stratégie d'emploi. Rapport No. 25456-TUN, Moyen-Orient et Afrique du Nord Secteurs sociaux (MNSHD), Washington DC.

World Bank. 2004b. Republic of Tunisia - Development Policy Review: Making Deeper Trade Integration Work for growth And Jobs. Report No. 29847-TUN, Social and Economic Development Group Middle East and North Africa Region, Washington DC. 


\section{ANNEXES}

\section{Annex 1 - Estimates of GDP elasticities of employment}

Table A1.1 - GDP elasticities of employment in the literature

\begin{tabular}{|c|c|c|}
\hline Authors & Country and period & Employment Elasticity \\
\hline Seyfried $^{\mathrm{a}}$ & USA (1990-2003) & 0.47 \\
\hline Boltho and Glyn (1995) ${ }^{\mathrm{b}}$ & OECD countries & $0.5-0.6$ \\
\hline $\begin{array}{l}\text { Padalino and Vivarelli } \\
(1997)^{\mathrm{C}}\end{array}$ & $\begin{array}{l}\text { USA and Canada } \\
\text { Japan, France, Germany, Italy, } \\
\text { UK }\end{array}$ & $\begin{array}{l}0.5 \\
\sim 0\end{array}$ \\
\hline Walterskirchen (1999) $^{\mathrm{d}}$ & $\begin{array}{l}\text { EU (1988-1998) } \\
\text { Austria }(1970-1998) \\
\text { Spain }(1970-1998) \\
\text { USA (1970-1998) }\end{array}$ & $\begin{array}{l}0.65 \\
0.24 \\
0.76 \\
0.53\end{array}$ \\
\hline World Bank (2004b) & $\begin{array}{l}\text { Tunisia }(1989-1994) \\
\text { Tunisia }(1994-1997) \\
\text { Tunisia }(1997-2001)\end{array}$ & $\begin{array}{l}\text { Agricult. -0.1, Manufact. 0.6, Services } 1.1 \\
\text { Agricult. 0.5, Manufact. 0.7, Services } 0.5 \\
\text { Agricult. 1.6, Manufact. 0.5, Services } 0.5\end{array}$ \\
\hline \multicolumn{3}{|c|}{ 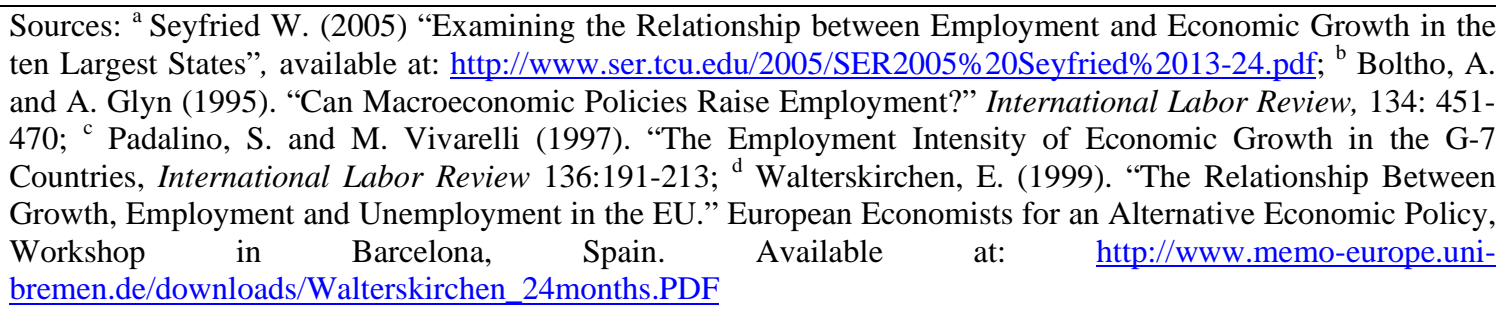 } \\
\hline
\end{tabular}

Table A1.2 - World and regional estimates of employment elasticities

\begin{tabular}{lcccccc}
\hline & Employment elasticities & \multicolumn{3}{c}{ Average annual GDP growth rates } \\
\hline & $1991-$ & $1995-$ & $1999-$ & $1991-$ & $1995-$ & $1999-$ \\
WORLD & 1995 & 1999 & 2003 & 1995 & 1999 & 2003 \\
Developed Economies and EU & 0.34 & 0.38 & 0.30 & 2.9 & 3.6 & 3.5 \\
Europe (non-EU) and CIS & 0.25 & 0.34 & 0.21 & 2.2 & 3.1 & 2.1 \\
East Asia & 0.28 & 0.21 & 0.10 & -7.8 & 0.5 & 6.2 \\
South-East Asia and the Pacific & 0.14 & 0.14 & 0.18 & 11.6 & 7.4 & 7.7 \\
South Asia & 0.39 & 0.20 & 0.42 & 7.4 & 1.6 & 4.8 \\
Latin America and the Caribbean & 0.40 & 0.49 & 0.36 & 6.0 & 5.8 & 5.1 \\
Middle East and North Africa & 0.64 & 0.68 & 0.41 & 3.4 & 2.8 & 1.4 \\
Sub-Saharan Africa & 0.66 & 1.01 & 0.70 & 3.1 & 3.7 & 4.3 \\
\hline
\end{tabular}

Source: ILO, http://www.ilo.org/public/english/employment/strat/kilm/download/kilm19.pdf 
Table A1.3 - Sectoral employment elasticities and average annual value-added growth rates (1991-2003)

\begin{tabular}{|c|c|c|c|c|c|c|}
\hline & \multicolumn{2}{|c|}{ Agriculture } & \multicolumn{2}{|c|}{ Industry } & \multicolumn{2}{|c|}{ Services } \\
\hline & $\begin{array}{c}\text { Elasticit } \\
\mathrm{y}\end{array}$ & $\begin{array}{c}\text { VA } \\
\text { growth }\end{array}$ & $\begin{array}{c}\text { Elasticit } \\
\mathrm{y}\end{array}$ & $\begin{array}{c}\text { VA } \\
\text { growth }\end{array}$ & $\begin{array}{c}\text { Elasticit } \\
\mathrm{y}\end{array}$ & $\begin{array}{c}\text { VA } \\
\text { growth }\end{array}$ \\
\hline WORLD & 0.41 & 2.0 & 0.28 & 2.1 & 0.57 & 3.0 \\
\hline Developed Economies and EU & -0.43 & 1.2 & 0.28 & 1.3 & 0.56 & 2.9 \\
\hline Europe (non-EU) and CIS & -0.24 & -0.1 & 0.29 & -0.4 & 0.25 & 1.5 \\
\hline East Asia & 0.23 & 3.7 & 0.06 & 12.5 & 0.50 & 8.8 \\
\hline South-East Asia and the Pacific & 0.20 & 2.1 & 0.68 & 5.4 & 0.99 & 4.6 \\
\hline South Asia & 0.71 & 2.9 & 0.37 & 5.9 & 0.36 & 6.9 \\
\hline Latin America and the Caribbean & -0.32 & 2.5 & 0.51 & 2.2 & 1.04 & 2.7 \\
\hline Middle East and North Africa & 1.06 & 3.3 & 0.35 & 2.0 & 0.73 & 4.4 \\
\hline Sub-Saharan Africa & 0.82 & 2.3 & 0.90 & 2.0 & 0.79 & 2.8 \\
\hline
\end{tabular}

Source: ILO, http://www.ilo.org/public/english/employment/strat/kilm/download/kilm19.pdf 


\section{Annex 2 - Youth unemployment outlook}

Table A2.1 - Projected youth unemployment rate

\begin{tabular}{lrrrrrr}
\hline Year & $\begin{array}{r}\text { GDP } \\
\text { growth }\end{array}$ & $\begin{array}{r}\text { Youth } \\
\text { Employment } \\
\text { growth }\end{array}$ & $\begin{array}{r}\text { GDP } \\
\text { elasticity of } \\
\text { youth } \\
\text { employment }\end{array}$ & $\begin{array}{r}\text { Youth } \\
\text { Population } \\
\text { growth }\end{array}$ & $\begin{array}{r}\text { Active } \\
\text { youth } \\
\text { growth }\end{array}$ & $\begin{array}{r}\text { Youth } \\
\text { Unemployment } \\
\text { rate }\end{array}$ \\
\hline 2005 & $3.97 \%$ & n/a & n/a & $1.86 \%$ & $1.27 \%$ & $25.6 \%$ \\
2006 & $5.55 \%$ & $2.59 \%$ & 0.47 & $1.72 \%$ & $1.83 \%$ & $25.1 \%$ \\
2007 & $6.31 \%$ & $0.29 \%$ & 0.05 & $1.64 \%$ & $1.51 \%$ & $26.0 \%$ \\
2008 & $4.60 \%$ & $1.09 \%$ & 0.24 & $1.36 \%$ & $1.40 \%$ & $26.2 \%$ \\
2009 & $3.00 \%$ & $0.71 \%$ & 0.24 & $1.04 \%$ & $0.18 \%$ & $25.8 \%$ \\
2010 & $3.70 \%$ & $0.88 \%$ & 0.24 & $0.64 \%$ & $0.37 \%$ & $25.4 \%$ \\
2011 & $1.60 \%$ & $0.38 \%$ & 0.24 & $0.24 \%$ & $0.27 \%$ & $25.3 \%$ \\
2012 & $4.50 \%$ & $1.07 \%$ & 0.24 & $-0.15 \%$ & $-0.27 \%$ & $24.3 \%$ \\
2013 & $4.50 \%$ & $1.07 \%$ & 0.24 & $-0.54 \%$ & $-0.55 \%$ & $23.1 \%$ \\
2014 & $4.50 \%$ & $1.07 \%$ & 0.24 & $-0.98 \%$ & $-1.01 \%$ & $21.5 \%$ \\
2015 & $4.50 \%$ & $1.07 \%$ & 0.24 & $-1.49 \%$ & $-1.48 \%$ & $19.5 \%$ \\
2016 & $4.50 \%$ & $1.07 \%$ & 0.24 & $-1.96 \%$ & $-1.98 \%$ & $17.0 \%$ \\
2017 & $4.50 \%$ & $1.07 \%$ & 0.24 & $-2.41 \%$ & $-2.50 \%$ & $13.9 \%$ \\
2018 & $4.50 \%$ & $1.07 \%$ & 0.24 & $-2.79 \%$ & $-2.76 \%$ & $10.5 \%$ \\
\hline
\end{tabular}

Source: Author's calculations based on African Economic Outlook, INS and ILO data, and authors' assumptions (red font for authors' projection).

Notes:

- The rates of growth of youth population and active youth population are from the ILO and refer to the 20-29 age group;

- The youth unemployment rate for the period 2005-07 was calculated by the authors on the basis of LFS data, and refers to the 23-29 age group; youth unemployment rates from 2008 are authors' estimates;

- GDP growth rates are from the African Economic Outlook (recorded up to 2009, estimated for 2010, and predicted for 2011-12); GDP growth rates from 2013 are assumed by the authors to be constant at the level of 2012;

- The rate of growth of youth employment in 2006 and 2007 is calculated by the authors on the basis of ILO and INS data; authors' projections for the period 2008-2018 are based on estimates of GDP growth and GDP elasticity of youth employment;

- The GDP elasticity of youth employment for 2006 and 2007 is estimated by the authors based on ILO and INS data; values from 2008 are the non-linear average of the elasticity for the period 2005-07 [((EMPL(97)/EMPL(95)-1)/ ((GDP(97)/GDP(95)-1)] and are assumed to be constant. 


\section{Annex 3 - Labor market dynamics}

Table A3.1 - Youth labor intensity and youth employment growth, by sector

\begin{tabular}{|c|c|c|c|c|c|c|}
\hline & $\begin{array}{r}\text { Employment, } \\
\text { non-enrolled } \\
\text { youth (a) } \\
\end{array}$ & $\begin{array}{r}\text { GDP, } \\
\text { TND } \\
\text { million } \\
\text { (current } \\
\text { prices) }\end{array}$ & $\begin{array}{r}\text { Youth labor } \\
\text { intensity } \\
\text { (share of total } \\
\text { employment } \\
\text { over share of } \\
\text { total GDP) (b) }\end{array}$ & $\begin{array}{r}\text { Yearly youth } \\
\text { employment } \\
\text { growth (c) }\end{array}$ & $\begin{array}{r}\text { Yearly } \\
\text { GDP } \\
\text { growth } \\
\end{array}$ & $\begin{array}{r}\text { GDP } \\
\text { elasticity of } \\
\text { youth } \\
\text { employment } \\
\text { (d) }\end{array}$ \\
\hline & & 2007 & & \multicolumn{3}{|c|}{ Average 2005-07 } \\
\hline $\begin{array}{l}\text { Agriculture, forestry and } \\
\text { fishery }\end{array}$ & 86,573 & 4641.3 & 1.26 & $-1.02 \%$ & $2.81 \%$ & -0.36 \\
\hline Agri-food industry & 13,219 & 1387.7 & 0.65 & $4.24 \%$ & $4.20 \%$ & 1.01 \\
\hline Building materials & 7,021 & 799.6 & 0.59 & $-4.41 \%$ & $3.55 \%$ & -1.19 \\
\hline $\begin{array}{l}\text { Mechanical and electrical } \\
\text { materials }\end{array}$ & 30,845 & 1739.5 & 1.20 & $6.22 \%$ & $13.78 \%$ & 0.44 \\
\hline Chemical industry & 5,916 & 765.3 & 0.52 & $13.40 \%$ & $1.60 \%$ & 8.89 \\
\hline Textile industry & 83,101 & 2046.9 & 2.75 & $0.32 \%$ & $1.66 \%$ & 0.19 \\
\hline Other manufacturing & 18,782 & 958.4 & 1.33 & $-4.52 \%$ & $4.58 \%$ & -0.94 \\
\hline Mining and refining & 2,038 & 2336.3 & 0.06 & $55.40 \%$ & $5.19 \%$ & 13.29 \\
\hline Electricity & 1,233 & 468.1 & 0.18 & $8.06 \%$ & $4.01 \%$ & 2.05 \\
\hline $\begin{array}{l}\text { Production and distribution of } \\
\text { water }\end{array}$ & 536 & 184.8 & 0.20 & $20.33 \%$ & $4.59 \%$ & 4.76 \\
\hline Constructions & 75,431 & 2368.6 & 2.16 & $5.66 \%$ & $3.95 \%$ & 1.44 \\
\hline Retail & 70,069 & 4309.6 & 1.10 & $3.62 \%$ & $5.76 \%$ & 0.62 \\
\hline $\begin{array}{l}\text { Transport and } \\
\text { telecommunications }\end{array}$ & 31,004 & 5020.3 & 0.42 & $13.72 \%$ & $13.91 \%$ & 0.99 \\
\hline Hotels and restaurants & 31,083 & 2546.6 & 0.83 & $5.48 \%$ & $3.65 \%$ & 1.52 \\
\hline Banks and Insurances & 3,198 & 1454.2 & 0.15 & $5.45 \%$ & $7.70 \%$ & 0.70 \\
\hline Real estates and repair & 28,709 & 4003.3 & 0.49 & $4.82 \%$ & $5.20 \%$ & 0.92 \\
\hline Non-market services & 116,956 & 6007.5 & 1.32 & $2.64 \%$ & $5.26 \%$ & 0.50 \\
\hline
\end{tabular}

Source: Authors' calculations based on INS and LFS 2005-07. Notes: In the different colors, grey highlighting indicates (a) sectors employing more than 50,000 youth; (b) sectors with youth labor intensity above 1; (c) sectors in which youth employment grows by more than 2 percent a year; (d) sectors with GDP elasticity of youth employment above 1. 
Table A3.2 - Conditional probability of transition, by sector of employment

\begin{tabular}{|c|c|c|c|c|c|}
\hline Mobility 2005-06, age 23-29 & $\begin{array}{l}\text { Became } \\
\text { inactive }\end{array}$ & $\begin{array}{c}\text { Become } \\
\text { unemployed }\end{array}$ & $\begin{array}{l}\text { Stayed in the } \\
\text { same sector }\end{array}$ & $\begin{array}{l}\text { Moved to } \\
\text { another } \\
\text { sector }\end{array}$ & Total \\
\hline Inactive & 0.768 & 0.077 & & 0.155 & 1.000 \\
\hline Unemployed & 0.215 & 0.393 & & 0.391 & 1.000 \\
\hline Agriculture, forestry and fishery & 0.228 & 0.092 & 0.494 & 0.185 & 1.000 \\
\hline Agri-food industry & 0.136 & 0.081 & 0.544 & 0.238 & 1.000 \\
\hline Building materials & 0.027 & 0.126 & 0.535 & 0.312 & 1.000 \\
\hline Mechanical and electrical materials & 0.083 & 0.070 & 0.534 & 0.313 & 1.000 \\
\hline Chemical industry & 0.071 & 0.103 & 0.472 & 0.353 & 1.000 \\
\hline Textile industry & 0.195 & 0.076 & 0.619 & 0.110 & 1.000 \\
\hline Other manufacturing & 0.076 & 0.068 & 0.605 & 0.251 & 1.000 \\
\hline Mining and refining & NR & NR & NR & NR & \\
\hline Electricity & NR & NR & NR & NR & \\
\hline Production and distribution of water & NR & NR & NR & NR & \\
\hline Constructions & 0.053 & 0.156 & 0.496 & 0.295 & 1.000 \\
\hline Retail & 0.108 & 0.127 & 0.511 & 0.254 & 1.000 \\
\hline Transport and telecommunications & 0.036 & 0.075 & 0.631 & 0.258 & 1.000 \\
\hline Hotels and restaurants & 0.119 & 0.085 & 0.565 & 0.231 & 1.000 \\
\hline Banks and Insurances & NR & NR & NR & NR & \\
\hline Real estates and repair & 0.068 & 0.119 & 0.439 & 0.374 & 1.000 \\
\hline Social and Cultural Services & 0.192 & 0.073 & 0.521 & 0.214 & 1.000 \\
\hline Education, health and public administration & 0.061 & 0.062 & 0.747 & 0.130 & 1.000 \\
\hline Extra-territorial activities & NR & NR & NR & NR & \\
\hline
\end{tabular}

Source: Authors' calculations based on LFS 2005 and 2006. Note: NR=not reliable, when the number of observations was not sufficiently large for the estimation of transition probabilities.

Table A3.3 - Conditional probabilities of transition for non-graduates

\begin{tabular}{|c|c|c|c|c|}
\hline \multirow[t]{2}{*}{ Total } & \multicolumn{3}{|c|}{2006} & \\
\hline & Inactive & Unemployed & Employed & Total \\
\hline Inactive & 0.771 & 0.072 & 0.157 & 1.000 \\
\hline 2005Unemployed & 0.230 & 0.361 & 0.408 & 1.000 \\
\hline Employed & 0.129 & 0.094 & 0.777 & 1.000 \\
\hline
\end{tabular}

\begin{tabular}{crrrr} 
Males & \multicolumn{3}{c}{2006} \\
& Inactive & Unemployed & Employed & Total \\
Inactive & 0.362 & 0.249 & 0.388 & 1.000 \\
2005Unemployed & 0.128 & 0.396 & 0.476 & 1.000 \\
Employed & 0.055 & 0.108 & 0.837 & 1.000
\end{tabular}

\begin{tabular}{crrrr}
\multicolumn{1}{l}{ Females } & \multicolumn{4}{c}{2006} \\
& Inactive & Unemployed & Employed & Total \\
Inactive & 0.833 & 0.045 & 0.122 & 1.000 \\
2005Unemployed & 0.442 & 0.289 & 0.269 & 1.000 \\
Employed & 0.291 & 0.062 & 0.647 & 1.000 \\
\hline
\end{tabular}

Source: Authors' calculations based on LFS 2005 and 2006. Sample size: 11000 
Table A3.4 - Conditional probabilities of transition for graduates

\begin{tabular}{|c|c|c|c|c|}
\hline \multirow[t]{2}{*}{ Total } & \multicolumn{3}{|c|}{2006} & \\
\hline & Inactive & Unemployed & Employed & Total \\
\hline Inactive & 0.286 & 0.460 & 0.254 & 1.000 \\
\hline 2005Unemployed & 0.113 & 0.575 & 0.312 & 1.000 \\
\hline Employed & 0.074 & 0.096 & 0.831 & 1.000 \\
\hline
\end{tabular}

\begin{tabular}{crrrrr} 
Males & \multicolumn{4}{c}{2006} \\
& & Inactive & Unemployed & Employed & Total \\
Inactive & 0.151 & 0.502 & 0.348 & 1.000 \\
2005Unemployed & 0.124 & 0.574 & 0.302 & 1.000 \\
\hline Employed & 0.104 & 0.066 & 0.829 & 1.000
\end{tabular}

\begin{tabular}{crrrr} 
Females & \multicolumn{4}{c}{2006} \\
Inactive & Inactive & Unemployed & Employed & Total \\
2005Unemployed & 0.370 & 0.434 & 0.196 & 1.000 \\
Employed & 0.104 & 0.575 & 0.321 & 1.000 \\
\hline Source: Authors' calculations based on LFS 2005 and 2006. Sample size: $~$ & 0.000
\end{tabular}

Source: Authors' calculations based on LFS 2005 and 2006. Sample size: 11000

Table A3.5 - Conditional Multinomial Logit regression of the determinants of the labor market state in 2006

\begin{tabular}{|c|c|c|c|}
\hline \multicolumn{4}{|c|}{+2} \\
\hline 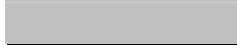 & \multirow[t]{2}{*}{1 - Inactive } & 2 - Unemployed & 3 - Employed \\
\hline \multicolumn{3}{|c|}{ State of Destination (2006) } & \\
\hline \multicolumn{4}{|c|}{1 - Inactive } \\
\hline Female & & $1.612 * * *$ & $2.119 * * *$ \\
\hline Masters & & $-.548 *$ & 0.330 \\
\hline Female*Masters & & $-2.094 * * *$ & $-2.740 * * *$ \\
\hline Constant & & $-1.157 * * *$ & $-2.781 * * *$ \\
\hline \multicolumn{4}{|l|}{2 - Unemployed } \\
\hline Female & $-2.625 * * *$ & & $-.308 * * *$ \\
\hline Masters & $1.260 *$ & & -0.389 \\
\hline Female*Masters & $1.932 * *$ & & $.979 * *$ \\
\hline Constant & $-0.279 * *$ & & $-1.967 * * *$ \\
\hline \multicolumn{4}{|l|}{3 - Employed } \\
\hline Female & $-2.054 * * *$ & $-.292 * *$ & \\
\hline Masters & 0.191 & $-.840 * * *$ & \\
\hline Female*Masters & 1.178 & 0.346 & \\
\hline Constant & 0.097 & $.147^{* *}$ & \\
\hline
\end{tabular}

Note: Authors' estimations based on LFS 2005 and 2006. Initial labor market state (in 2005) taken as reference (omitted category). 


\section{Annex 4 - Static analysis: labor market profile}

Table A4.1 - Employment by sector and gender, 2007

\begin{tabular}{lccc}
\hline Share of employment & Males & Females & Total \\
\hline Agriculture, forestry and fishery & 0.152 & 0.123 & 0.143 \\
Agri-food industry & 0.024 & 0.017 & 0.022 \\
Building materials & 0.015 & 0.004 & 0.012 \\
Mechanical and electrical materials & 0.044 & 0.065 & 0.051 \\
Chemical industry & 0.010 & 0.010 & 0.010 \\
Textile industry & 0.050 & 0.320 & 0.137 \\
Other manufacturing & 0.039 & 0.015 & 0.031 \\
Mining and refining & 0.005 & 0.001 & 0.003 \\
Electricity & 0.003 & 0.001 & 0.002 \\
Production and distribution of water & 0.001 & 0.001 & 0.001 \\
Constructions & 0.181 & 0.008 & 0.125 \\
Retail & 0.134 & 0.077 & 0.116 \\
Transport and telecommunications & 0.061 & 0.030 & 0.051 \\
Hotels and restaurants & 0.064 & 0.024 & 0.051 \\
Banks and Insurances & 0.005 & 0.006 & 0.005 \\
Real estates and repair & 0.054 & 0.034 & 0.047 \\
Social and cultural services & 0.039 & 0.081 & 0.053 \\
Education, health and public admin. & 0.120 & 0.184 & 0.140 \\
\hline Total & 1.000 & 1.000 & 1.000 \\
\hline Source: Auhors
\end{tabular}

Source: Authors’ calculations based on LFS 2007. Sample size: 67150

Table A4.2 - Education by gender

\begin{tabular}{lccc}
\hline Age 23-29, not enrolled & Males & Females & Total \\
\hline Less than secondary & 0.713 & 0.722 & 0.717 \\
Secondary (BAC) & 0.148 & 0.115 & 0.131 \\
Vocational training & 0.063 & 0.066 & 0.065 \\
Total without university degree & 0.924 & 0.903 & 0.913 \\
& & & \\
Masters in Social Sciences & 0.009 & 0.027 & 0.018 \\
$\quad$ Economics, Management or Law & 0.024 & 0.031 & 0.027 \\
$\quad$ Hard sciences & 0.011 & 0.010 & 0.010 \\
$\quad$ Other discipline & 0.013 & 0.017 & 0.015 \\
Degree in Engineering & 0.013 & 0.004 & 0.009 \\
Degree in Medicine or Pharmacy & 0.002 & 0.003 & 0.002 \\
PhD & 0.005 & 0.005 & 0.005 \\
Total with university degree & 0.076 & 0.097 & 0.087 \\
& & & \\
Total & 1.000 & 1.000 & 1.000 \\
\hline Sourc: Author
\end{tabular}

Source: Authors' calculations based on LFS 2007. Sample size: 67150 
Table A4.3 - Labor market state, by education and gender

\begin{tabular}{|c|c|c|c|c|c|c|c|c|}
\hline \multirow[b]{2}{*}{ Total } & \multicolumn{3}{|c|}{ Youth } & \multicolumn{5}{|c|}{ Active youth } \\
\hline & Inactive & Active & Total & $\begin{array}{l}\text { Unempl- } \\
\text { oyed }\end{array}$ & $\begin{array}{c}\text { Regular } \\
\text { wage } \\
\text { empl. }\end{array}$ & $\begin{array}{l}\text { Casual } \\
\text { wage } \\
\text { empl. }\end{array}$ & $\begin{array}{l}\text { Self- } \\
\text { empl. }\end{array}$ & Total \\
\hline Less than secondary & 0.368 & 0.632 & 1.000 & 0.205 & 0.473 & 0.099 & 0.223 & 1.000 \\
\hline Secondary (BAC) & 0.155 & 0.846 & 1.000 & 0.298 & 0.491 & 0.051 & 0.160 & 1.000 \\
\hline Vocational training & 0.052 & 0.948 & 1.000 & 0.409 & 0.514 & 0.026 & 0.051 & 1.000 \\
\hline Masters in Social Sciences & 0.059 & 0.941 & 1.000 & 0.432 & 0.518 & 0.024 & 0.026 & 1.000 \\
\hline Economics, Management or Law & 0.060 & 0.940 & 1.000 & 0.471 & 0.451 & 0.018 & 0.059 & 1.000 \\
\hline Hard sciences & 0.026 & 0.974 & 1.000 & 0.405 & 0.535 & 0.022 & 0.037 & 1.000 \\
\hline Other discipline & 0.067 & 0.933 & 1.000 & 0.373 & 0.577 & 0.012 & 0.038 & 1.000 \\
\hline Degree in Engineering & 0.038 & 0.962 & 1.000 & 0.245 & 0.697 & 0.019 & 0.039 & 1.000 \\
\hline Degree in Medicine or Pharmacy & 0.047 & 0.953 & 1.000 & 0.295 & 0.499 & 0.003 & 0.203 & 1.000 \\
\hline $\mathrm{PhD}$ & 0.039 & 0.961 & 1.000 & 0.268 & 0.642 & 0.031 & 0.060 & 1.000 \\
\hline Males & Inactive & Active & Total & $\begin{array}{c}\text { Unempl- } \\
\text { oyed }\end{array}$ & $\begin{array}{c}\text { Regular } \\
\text { wage } \\
\text { empl. }\end{array}$ & $\begin{array}{l}\text { Casual } \\
\text { wage } \\
\text { empl. }\end{array}$ & $\begin{array}{l}\text { Self- } \\
\text { empl. }\end{array}$ & Total \\
\hline Less than secondary & 0.095 & 0.905 & 1.000 & 0.209 & 0.423 & 0.121 & 0.248 & 1.000 \\
\hline Secondary (BAC) & 0.031 & 0.969 & 1.000 & 0.286 & 0.468 & 0.065 & 0.182 & 1.000 \\
\hline Vocational training & 0.019 & 0.981 & 1.000 & 0.343 & 0.556 & 0.030 & 0.072 & 1.000 \\
\hline Masters in Social Sciences & 0.029 & 0.971 & 1.000 & 0.411 & 0.519 & 0.031 & 0.038 & 1.000 \\
\hline Economics, Management or Law & 0.030 & 0.970 & 1.000 & 0.396 & 0.500 & 0.021 & 0.083 & 1.000 \\
\hline Hard sciences & 0.007 & 0.993 & 1.000 & 0.361 & 0.574 & 0.015 & 0.050 & 1.000 \\
\hline Other discipline & 0.042 & 0.958 & 1.000 & 0.303 & 0.632 & 0.006 & 0.060 & 1.000 \\
\hline Degree in Engineering & 0.016 & 0.984 & 1.000 & 0.207 & 0.735 & 0.018 & 0.040 & 1.000 \\
\hline Degree in Medicine or Pharmacy & 0.028 & 0.973 & 1.000 & 0.210 & 0.501 & 0.000 & 0.289 & 1.000 \\
\hline $\mathrm{PhD}$ & 0.000 & 1.000 & 1.000 & 0.213 & 0.697 & 0.036 & 0.054 & 1.000 \\
\hline Females & Inactive & Active & Total & $\begin{array}{c}\text { Unempl- } \\
\text { oyed }\end{array}$ & $\begin{array}{c}\text { Regular } \\
\text { wage } \\
\text { empl. }\end{array}$ & $\begin{array}{l}\text { Casual } \\
\text { wage } \\
\text { empl. }\end{array}$ & $\begin{array}{l}\text { Self- } \\
\text { empl. }\end{array}$ & Total \\
\hline Less than secondary & 0.643 & 0.357 & 1.000 & 0.195 & 0.601 & 0.045 & 0.158 & 1.000 \\
\hline Secondary (BAC) & 0.319 & 0.681 & 1.000 & 0.322 & 0.535 & 0.024 & 0.119 & 1.000 \\
\hline Vocational training & 0.084 & 0.916 & 1.000 & 0.479 & 0.469 & 0.022 & 0.029 & 1.000 \\
\hline Masters in Social Sciences & 0.070 & 0.931 & 1.000 & 0.440 & 0.517 & 0.021 & 0.022 & 1.000 \\
\hline Economics, Management or Law & 0.085 & 0.916 & 1.000 & 0.534 & 0.410 & 0.016 & 0.039 & 1.000 \\
\hline Hard sciences & 0.048 & 0.952 & 1.000 & 0.460 & 0.486 & 0.032 & 0.022 & 1.000 \\
\hline Other discipline & 0.087 & 0.914 & 1.000 & 0.433 & 0.531 & 0.017 & 0.019 & 1.000 \\
\hline Degree in Engineering & 0.104 & 0.897 & 1.000 & 0.371 & 0.575 & 0.020 & 0.034 & 1.000 \\
\hline Degree in Medicine or Pharmacy & 0.064 & 0.936 & 1.000 & 0.374 & 0.497 & 0.005 & 0.124 & 1.000 \\
\hline $\mathrm{PhD}$ & 0.082 & 0.918 & 1.000 & 0.331 & 0.577 & 0.024 & 0.067 & 1.000 \\
\hline
\end{tabular}

Source: Authors' calculations based on LFS 2007. Sample size: 67150 
Table A4.4 - Skill level, by education and gender

\begin{tabular}{|c|c|c|c|c|c|c|c|}
\hline Total & $\begin{array}{l}\text { High } \\
\text { skill }\end{array}$ & $\begin{array}{c}\text { Interme- } \\
\text { diate } \\
\text { skill }\end{array}$ & $\begin{array}{l}\text { Low } \\
\text { skill }\end{array}$ & Total & $\begin{array}{c}\text { Share } \\
\text { without } \\
\text { contract }\end{array}$ & $\begin{array}{c}\text { Share } \\
\text { with } \\
\text { contract }\end{array}$ & Total \\
\hline Less than secondary & 0.078 & 0.648 & 0.275 & 1.000 & 0.450 & 0.550 & 1.000 \\
\hline Secondary (BAC) & 0.100 & 0.798 & 0.102 & 1.000 & 0.320 & 0.680 & 1.000 \\
\hline Vocational training & 0.087 & 0.881 & 0.032 & 1.000 & 0.165 & 0.835 & 1.000 \\
\hline Masters in Social Sciences & 0.726 & 0.263 & 0.012 & 1.000 & 0.185 & 0.815 & 1.000 \\
\hline Economics, Management or Law & 0.595 & 0.392 & 0.013 & 1.000 & 0.156 & 0.844 & 1.000 \\
\hline Hard sciences & 0.772 & 0.223 & 0.005 & 1.000 & 0.115 & 0.885 & 1.000 \\
\hline Other discipline & 0.630 & 0.354 & 0.016 & 1.000 & 0.089 & 0.911 & 1.000 \\
\hline Degree in Engineering & 0.896 & 0.096 & 0.009 & 1.000 & 0.109 & 0.891 & 1.000 \\
\hline Degree in Medicine or Pharmacy & 0.899 & 0.101 & 0.000 & 1.000 & 0.225 & 0.775 & 1.000 \\
\hline $\mathrm{PhD}$ & 0.857 & 0.136 & 0.007 & 1.000 & 0.104 & 0.896 & 1.000 \\
\hline Males & $\begin{array}{l}\text { High } \\
\text { skill }\end{array}$ & $\begin{array}{c}\text { Interme- } \\
\text { diate } \\
\text { skill }\end{array}$ & $\begin{array}{l}\text { Low } \\
\text { skill }\end{array}$ & Total & $\begin{array}{c}\text { Share } \\
\text { without } \\
\text { contract }\end{array}$ & $\begin{array}{c}\text { Share } \\
\text { with } \\
\text { contract }\end{array}$ & Total \\
\hline Less than secondary & 0.095 & 0.610 & 0.295 & 1.000 & 0.518 & 0.482 & 1.000 \\
\hline Secondary (BAC) & 0.115 & 0.771 & 0.115 & 1.000 & 0.362 & 0.638 & 1.000 \\
\hline Vocational training & 0.104 & 0.857 & 0.038 & 1.000 & 0.163 & 0.837 & 1.000 \\
\hline Masters in Social Sciences & 0.707 & 0.267 & 0.026 & 1.000 & 0.192 & 0.808 & 1.000 \\
\hline Economics, Management or Law & 0.667 & 0.314 & 0.020 & 1.000 & 0.137 & 0.863 & 1.000 \\
\hline Hard sciences & 0.783 & 0.209 & 0.008 & 1.000 & 0.121 & 0.879 & 1.000 \\
\hline Other discipline & 0.672 & 0.299 & 0.029 & 1.000 & 0.102 & 0.898 & 1.000 \\
\hline Degree in Engineering & 0.898 & 0.095 & 0.007 & 1.000 & 0.114 & 0.886 & 1.000 \\
\hline Degree in Medicine or Pharmacy & 0.952 & 0.048 & 0.000 & 1.000 & 0.319 & 0.681 & 1.000 \\
\hline $\mathrm{PhD}$ & 0.868 & 0.132 & 0.000 & 1.000 & 0.104 & 0.896 & 1.000 \\
\hline Females & $\begin{array}{l}\text { High } \\
\text { skill }\end{array}$ & $\begin{array}{c}\text { Interme- } \\
\text { diate } \\
\text { skill }\end{array}$ & $\begin{array}{l}\text { Low } \\
\text { skill }\end{array}$ & Total & $\begin{array}{c}\text { Share } \\
\text { without } \\
\text { contract }\end{array}$ & $\begin{array}{c}\text { Share } \\
\text { with } \\
\text { contract }\end{array}$ & Total \\
\hline Less than secondary & 0.035 & 0.741 & 0.224 & 1.000 & 0.304 & 0.696 & 1.000 \\
\hline Secondary (BAC) & 0.072 & 0.851 & 0.078 & 1.000 & 0.244 & 0.756 & 1.000 \\
\hline Vocational training & 0.065 & 0.910 & 0.025 & 1.000 & 0.168 & 0.832 & 1.000 \\
\hline Masters in Social Sciences & 0.733 & 0.261 & 0.006 & 1.000 & 0.183 & 0.817 & 1.000 \\
\hline Economics, Management or Law & 0.521 & 0.472 & 0.007 & 1.000 & 0.175 & 0.825 & 1.000 \\
\hline Hard sciences & 0.756 & 0.244 & 0.000 & 1.000 & 0.105 & 0.895 & 1.000 \\
\hline Other discipline & 0.588 & 0.409 & 0.003 & 1.000 & 0.076 & 0.924 & 1.000 \\
\hline Degree in Engineering & 0.888 & 0.097 & 0.014 & 1.000 & 0.087 & 0.913 & 1.000 \\
\hline Degree in Medicine or Pharmacy & 0.840 & 0.160 & 0.000 & 1.000 & 0.138 & 0.862 & 1.000 \\
\hline $\mathrm{PhD}$ & 0.843 & 0.141 & 0.016 & 1.000 & 0.103 & 0.897 & 1.000 \\
\hline
\end{tabular}

Source: Authors’ calculations based on LFS 2007. Sample size: 67150 
Table A4.5 - Sector of employment, by education and gender

\begin{tabular}{|c|c|c|c|c|c|}
\hline Total & Unemployed & $\begin{array}{c}\text { In } \\
\text { Agriculture }\end{array}$ & $\begin{array}{c}\text { Industry and } \\
\text { private } \\
\text { services }\end{array}$ & $\begin{array}{l}\text { In public } \\
\text { services }\end{array}$ & $\begin{array}{c}\text { Total } \\
\text { employment }\end{array}$ \\
\hline Less than secondary & 0.203 & 0.152 & 0.551 & 0.094 & 1.000 \\
\hline Secondary (BAC) & 0.294 & 0.040 & 0.506 & 0.160 & 1.000 \\
\hline Vocational training & 0.404 & 0.017 & 0.324 & 0.255 & 1.000 \\
\hline Masters in Social Sciences & 0.429 & 0.003 & 0.083 & 0.485 & 1.000 \\
\hline Economics, Management or Law & 0.467 & 0.010 & 0.379 & 0.144 & 1.000 \\
\hline Hard sciences & 0.402 & 0.010 & 0.101 & 0.486 & 1.000 \\
\hline Other discipline & 0.373 & 0.004 & 0.231 & 0.392 & 1.000 \\
\hline Degree in Engineering & 0.243 & 0.017 & 0.593 & 0.148 & 1.000 \\
\hline Degree in Medicine or Pharmacy & 0.292 & 0.000 & 0.141 & 0.567 & 1.000 \\
\hline $\mathrm{PhD}$ & 0.268 & 0.002 & 0.253 & 0.477 & 1.000 \\
\hline Males & Unemployed & $\begin{array}{c}\text { In } \\
\text { Agriculture }\end{array}$ & $\begin{array}{c}\text { Industry and } \\
\text { private } \\
\text { services }\end{array}$ & $\begin{array}{l}\text { In public } \\
\text { services }\end{array}$ & $\begin{array}{c}\text { Total } \\
\text { employment }\end{array}$ \\
\hline Less than secondary & 0.208 & 0.154 & 0.550 & 0.089 & 1.000 \\
\hline Secondary (BAC) & 0.283 & 0.044 & 0.533 & 0.140 & 1.000 \\
\hline Vocational training & 0.342 & 0.017 & 0.422 & 0.219 & 1.000 \\
\hline Masters in Social Sciences & 0.407 & 0.009 & 0.108 & 0.476 & 1.000 \\
\hline Economics, Management or Law & 0.394 & 0.010 & 0.459 & 0.137 & 1.000 \\
\hline Hard sciences & 0.358 & 0.018 & 0.123 & 0.501 & 1.000 \\
\hline Other discipline & 0.303 & 0.004 & 0.301 & 0.393 & 1.000 \\
\hline Degree in Engineering & 0.206 & 0.018 & 0.632 & 0.144 & 1.000 \\
\hline Degree in Medicine or Pharmacy & 0.209 & 0.000 & 0.087 & 0.705 & 1.000 \\
\hline $\mathrm{PhD}$ & 0.215 & 0.000 & 0.343 & 0.443 & 1.000 \\
\hline Females & Unemployed & $\begin{array}{c}\text { In } \\
\text { Agriculture }\end{array}$ & $\begin{array}{c}\text { Industry and } \\
\text { private } \\
\text { services }\end{array}$ & $\begin{array}{l}\text { In public } \\
\text { services }\end{array}$ & $\begin{array}{c}\text { Total } \\
\text { employment }\end{array}$ \\
\hline Less than secondary & 0.190 & 0.148 & 0.554 & 0.108 & 1.000 \\
\hline Secondary (BAC) & 0.314 & 0.032 & 0.455 & 0.199 & 1.000 \\
\hline Vocational training & 0.469 & 0.016 & 0.222 & 0.292 & 1.000 \\
\hline Masters in Social Sciences & 0.437 & 0.000 & 0.074 & 0.488 & 1.000 \\
\hline Economics, Management or Law & 0.528 & 0.009 & 0.313 & 0.150 & 1.000 \\
\hline Hard sciences & 0.457 & 0.000 & 0.074 & 0.468 & 1.000 \\
\hline Other discipline & 0.431 & 0.005 & 0.173 & 0.391 & 1.000 \\
\hline Degree in Engineering & 0.358 & 0.014 & 0.468 & 0.160 & 1.000 \\
\hline Degree in Medicine or Pharmacy & 0.367 & 0.000 & 0.191 & 0.441 & 1.000 \\
\hline $\mathrm{PhD}$ & 0.329 & 0.005 & 0.150 & 0.516 & 1.000 \\
\hline
\end{tabular}


Table A4.6 - Multinomial logit regression of the determinants of the labor market state in 2007

\begin{tabular}{|c|c|c|c|}
\hline & \multicolumn{3}{|c|}{ Coefficient Standard error P value } \\
\hline \multicolumn{4}{|c|}{ Labor Force State: inactive (omitted: unemployed) } \\
\hline Dummy: female & 2.621 & 0.030 & 0.000 \\
\hline Dummy: Masters & -1.733 & 0.146 & 0.000 \\
\hline Interaction: female with Masters & -1.677 & 0.165 & 0.000 \\
\hline Age (years) & 0.139 & 0.006 & 0.000 \\
\hline Region North East (omitted Tunis) & 0.126 & 0.051 & 0.014 \\
\hline North-West & -0.417 & 0.046 & 0.000 \\
\hline Centre-West & 0.128 & 0.045 & 0.004 \\
\hline Centre-East & 0.283 & 0.048 & 0.000 \\
\hline South-West & 0.281 & 0.046 & 0.000 \\
\hline South-East & 0.028 & 0.048 & 0.555 \\
\hline Dummy: rural area & 0.664 & 0.028 & 0.000 \\
\hline Constant & -4.968 & 0.172 & 0.000 \\
\hline \multicolumn{4}{|c|}{ Labor Force State: regular wage earner } \\
\hline Dummy: female & 0.104 & 0.026 & 0.000 \\
\hline Dummy: Masters & -0.291 & 0.052 & 0.000 \\
\hline Interaction: female with Masters & -0.454 & 0.069 & 0.000 \\
\hline Age (years) & 0.133 & 0.006 & 0.000 \\
\hline Region North East (omitted Tunis) & 0.314 & 0.043 & 0.000 \\
\hline North-West & -1.155 & 0.042 & 0.000 \\
\hline Centre-West & 0.224 & 0.037 & 0.000 \\
\hline Centre-East & -1.012 & 0.048 & 0.000 \\
\hline South-West & -0.694 & 0.042 & 0.000 \\
\hline South-East & -1.083 & 0.044 & 0.000 \\
\hline Dummy: rural area & -0.248 & 0.027 & 0.000 \\
\hline Constant & -2.559 & 0.158 & 0.000 \\
\hline \multicolumn{4}{|c|}{ Labor Force State: casual/seasonal wage earner } \\
\hline Dummy: female & -1.152 & 0.051 & 0.000 \\
\hline Dummy: Masters & -2.280 & 0.173 & 0.000 \\
\hline Interaction: female with Masters & 1.293 & 0.219 & 0.000 \\
\hline Age (years) & 0.113 & 0.010 & 0.000 \\
\hline Region North East (omitted Tunis) & 1.270 & 0.087 & 0.000 \\
\hline North-West & 0.518 & 0.084 & 0.000 \\
\hline Centre-West & 1.098 & 0.082 & 0.000 \\
\hline Centre-East & 1.087 & 0.085 & 0.000 \\
\hline South-West & 1.123 & 0.083 & 0.000 \\
\hline South-East & 0.807 & 0.085 & 0.000 \\
\hline Dummy: rural area & 0.479 & 0.041 & 0.000 \\
\hline Constant & -4.793 & 0.262 & 0.000 \\
\hline \multicolumn{4}{|l|}{ Labor Force State: self-employed } \\
\hline Dummy: female & -0.665 & 0.033 & 0.000 \\
\hline Dummy: Masters & -1.816 & 0.099 & 0.000 \\
\hline Interaction: female with Masters & -0.091 & 0.151 & 0.546 \\
\hline Age (years) & 0.143 & 0.007 & 0.000 \\
\hline Region North East (omitted Tunis) & 0.589 & 0.059 & 0.000 \\
\hline North-West & 0.073 & 0.054 & 0.175 \\
\hline Centre-West & 0.395 & 0.055 & 0.000 \\
\hline Centre-East & 0.685 & 0.055 & 0.000 \\
\hline South-West & 0.295 & 0.057 & 0.000 \\
\hline
\end{tabular}


South-East

Dummy: rural area

Constant

Source: Authors' estimations based on LFS 2007. Number of observa
0.112

0.788

$-4.396$

0.0310 .000

$0.195 \quad 0.000$ 